In all probability, also, at a given moment in the years of emigration, and as if responding to a general call, the Lemmings will deseend from their respective mountains, unite their bands at the base, and continue their march across the country. This march is made in columns more or less close, according to the number of emigrants, which diminishes from day to day by death. In inhabited districts, numbers perish by the agency of man and the domestic animals (the dog, cat, and pig); and the wild animals which follow their columns wage a continual war upon them : these are the birds of prey, and, among mammals, the Isatis and the fox. It is also asserted that the reindeer, notwithstanding its herbivorous nature, does not spare them. Hence the Lemmings quit their mountains never to see them again; but it is not known whether the emigrants consist of old or young individuals.

The author procured five specimens, with the view of bringing them to France; but three of them died before he quitted Norway. They fed freely upon biscuit, and also ate walnuts, nuts, almonds, and raisins, which were varied on the voyage with some fruits from their mountains._Comptes Rendus, Sept. 7, 1863, p. 486.

\title{
Description of a new Species of Galago.
}

By A. D. Bartlett.

In the month of November last I had occasion to call at the house of Mr. L. A. Monteiro, and that gentleman showed me a specimen of a Galago. I at once told him that the animal was new and unknown to me. It differs from the known species in being larger and lighter in colour and in having a much longer tail. Mr. Monteiro informs me that it was sent to England by his son, Mr. J. J. Monteiro, who obtained it at Cuio Bay, to the south of Loando, in Angola. It is very gentle, and sleeps much during the day, feeds on fruit, bread, milk, and other sweet things, particularly bananas.

The entire length of the animal is 28 inches, of which the tail measures 16 inches.

The colour is light chinchilla grey all over the head, body, and tail, nearly white on the throat ; the toes and feet dark brown, nearly black; nose black; the eyes greyish brown; the ears nearly black, 2 inches long, $1 \frac{1}{2}$ inch broad at the base. The animal has the power of turning its ears back and folding them up when at rest: when moving about or in search of food, they spread out and stand upward and forward, reminding one of the Aye-Aye; but when folded back and down, the animal's face bears a strong resemblance to the Douroucouli. The pupils of the eyes are oval and vertical.

This animal is considerably larger than the specimen in the British Museum, known as Otolicnus crassicaudatus; but as I am unable to determine the exact structure of its teeth, in order to say positively that it belongs to that genus, I propose to name it Galago Monteiri, in order to identify it with the gentleman who has added from time to time many rare specimens to our collection.-Proc. Zool. Soc. June 9, 1863. 


\section{$2 \mathrm{BHL}$ Biodiversity Heritage Library}

Bartlett, Abraham Dee. 1863. "Description of a new species of Galago." The Annals and magazine of natural history; zoology, botany, and geology 12, 408-408.

View This Item Online: https://www.biodiversitylibrary.org/item/88262

Permalink: https://www.biodiversitylibrary.org/partpdf/65176

\section{Holding Institution}

Smithsonian Libraries

\section{Sponsored by}

Smithsonian

\section{Copyright \& Reuse}

Copyright Status: Public domain. The BHL considers that this work is no longer under copyright protection.

This document was created from content at the Biodiversity Heritage Library, the world's largest open access digital library for biodiversity literature and archives. Visit BHL at https://www.biodiversitylibrary.org. 